\title{
Noninvasive sampling of the distal airspace via HME-filter fluid is not useful to detect SARS-CoV-2 in intubated patients
}

Joerg Reifart ${ }^{1,2^{*}} \mathbb{D}$, Christoph Liebetrau ${ }^{1,2}$, Christian Troidl ${ }^{1,2}$, Katharina Madlener $^{3}$ and Andreas Rolf ${ }^{1,2}$

Keywords: SARS-CoV-2, PCR, BAL, HME, Infection

Sampling for SARS-CoV-2 is often carried out via bronchoscopy in intubated patients if upper respiratory samples at nasopharyngeal and oropharyngeal sites are negative or cannot be readily obtained [1]. PCR for detection of SARS-CoV-2 has been reported to have the highest sensitivity in lower respiratory tract samples [2]. Because bronchoscopy is an aerosol-generating procedure, alternative sampling methods with a similar sensitivity are of value. Previously, it has been demonstrated that heat moisture exchanger (HME) filter fluid had a composition approximating that of the fluid in the distal airspace (which is obtained during bronchoalveolar lavage) and can be used to test for pathogens [3-5].

The present investigation examined whether performing PCR for SARS-CoV-2 on unprocessed HME filter fluid is a viable method to test patients for infection instead of performing bronchoalveolar lavage via bronchoscopy.

Patients who had tested positive for SARS-CoV-2 and were treated with invasive ventilation for at least $12 \mathrm{~h}$ were enrolled prospectively (Fig. 1). The enrollment period was from May 2020 to December 2020. The initial test yielding the positive result was conducted using a nasopharyngeal swab.

HME filters were swabbed with a regular swab on the septic side of the filter. The swabs were then placed in

*Correspondence: j.reifart@kerckhoff-klinik.de

1 Department of Cardiology, Kerckhoff Heart Center, Benekestr. 2-8, 61231 Bad Nauheim, Germany

Full list of author information is available at the end of the article virus medium. SARS-CoV-2 PCR test systems used were either the BD MAX ${ }^{\mathrm{TM}}$ System with BioGX SARS-CoV-2 reagents (BD Life Sciences, Sparks, Maryland, USA) or the Hain Lifescience FluoroType ${ }^{\circledR}$ SARS-CoV-2 plus (Hain Lifescience GmbH, Nehren, Germany). Results of the tests of samples from the HME filters were compared with the results from the nasopharyngeal swab.

A sample size of 60 patients appeared to be adequate to compare the two different test methods. This report provides data for the initial 4 patients included in this prospective population.

Informed consent was acquired. If the patient was not able to provide informed consent, inclusion occured via an investigator consilium ("Giessener Lösung"). The ethics board of the state of Hessen, Germany, approved the study (AZ 79/20). The data collected from all patients were pseudonymized and entered into a database.

The trial was retrospectively registered on November 1st 2020 (DRKS registry; registration: DRKS00023494).

Four patients with positive nasopharyngeal swabs were enrolled in the study before an interim analysis of the results showed that it was unlikely that a sensitivity of greater than $90 \%$ would be reached. The enrollment was stopped prematurely. Of the 4 HME filter samples assayed, 3 did not test positive for SARS-CoV-2. All patients still tested positive in a bronchoalveolar lavage sample at a later point in time. Further results are provided in Table 1.

Bronchoscopy with bronchoalveolar lavage is commonly used to test for SARS-CoV-2 in intubated patients. This study was designed to determine whether sampling original author(s) and the source, provide a link to the Creative Commons licence, and indicate if changes were made. The images or other third party material in this article are included in the article's Creative Commons licence, unless indicated otherwise in a credit line to the material. If material is not included in the article's Creative Commons licence and your intended use is not permitted by statutory regulation or exceeds the permitted use, you will need to obtain permission directly from the copyright holder. To view a copy of this licence, visit http://creativecommons.org/licenses/by/4.0/. The Creative Commons Public Domain Dedication waiver (http://creativeco mmons.org/publicdomain/zero/1.0/) applies to the data made available in this article, unless otherwise stated in a credit line to the data. 
Table 1 Patient and testing data

\begin{tabular}{|c|c|c|c|c|}
\hline Variable & Patient 1 & Patient 2 & Patient 3 & Patient 4 \\
\hline Age, $y$ & 72 & 85 & 79 & 66 \\
\hline Female sex & Yes & No & No & Yes \\
\hline Body-mass index, kg/m [2] & 33 & 27 & 24 & 33 \\
\hline $\mathrm{CT} /$ chest X-ray morphology for COVID-19 & Yes & Yes & Yes & Yes \\
\hline Time from first positive PCR test until HME swab, $\mathrm{h}$ & 74 & 19 & 222 & 235 \\
\hline Time on ventilator until HME swab, h & 68 & 19 & 212 & 159 \\
\hline Time on ventilator (total), $\mathrm{h}$ & 494 & 243 & 369 & 159 \\
\hline SARS-CoV-2-positive HME PCR samples & Yes & No & No & No \\
\hline SARS-CoV-2-positive PCR samples after HME PCR testing (BAL) & Yes & Yes & Yes & Yes \\
\hline Therapy with corticosteroid & Yes & Yes & Yes & Yes \\
\hline Therapy with azithromycin & Yes & Yes & Yes & Yes \\
\hline Antiviral medication & No & No & No & No \\
\hline Death within 30 days & No & Yes & Yes & No \\
\hline
\end{tabular}

HME filter fluid may present a feasible and safer alternative. Our preliminary data showed that HME filter fluid alone, without any additional processing, is not suitable for the detection of SARS-CoV-2 via PCR.

Given the manifest disease in the lung as observed in CT scans, a positive SARS-CoV-2 swab in the upper respiratory tract without the lungs being affected is unlikely in patients needing invasive ventilation. Hence, the reason for the negative results remain unclear.
Unfortunately, the study did not control for prior inhalation therapy. Some of the fluid could have been nebulized saline instead of precipitated moisture from the distal airspace carrying viral RNA. Even so, viral RNA should still be detectable under these conditions.

Further processing of the samples, including the extraction of more liquid via centrifugation of the HME filters, might yield better results, though processing steps would

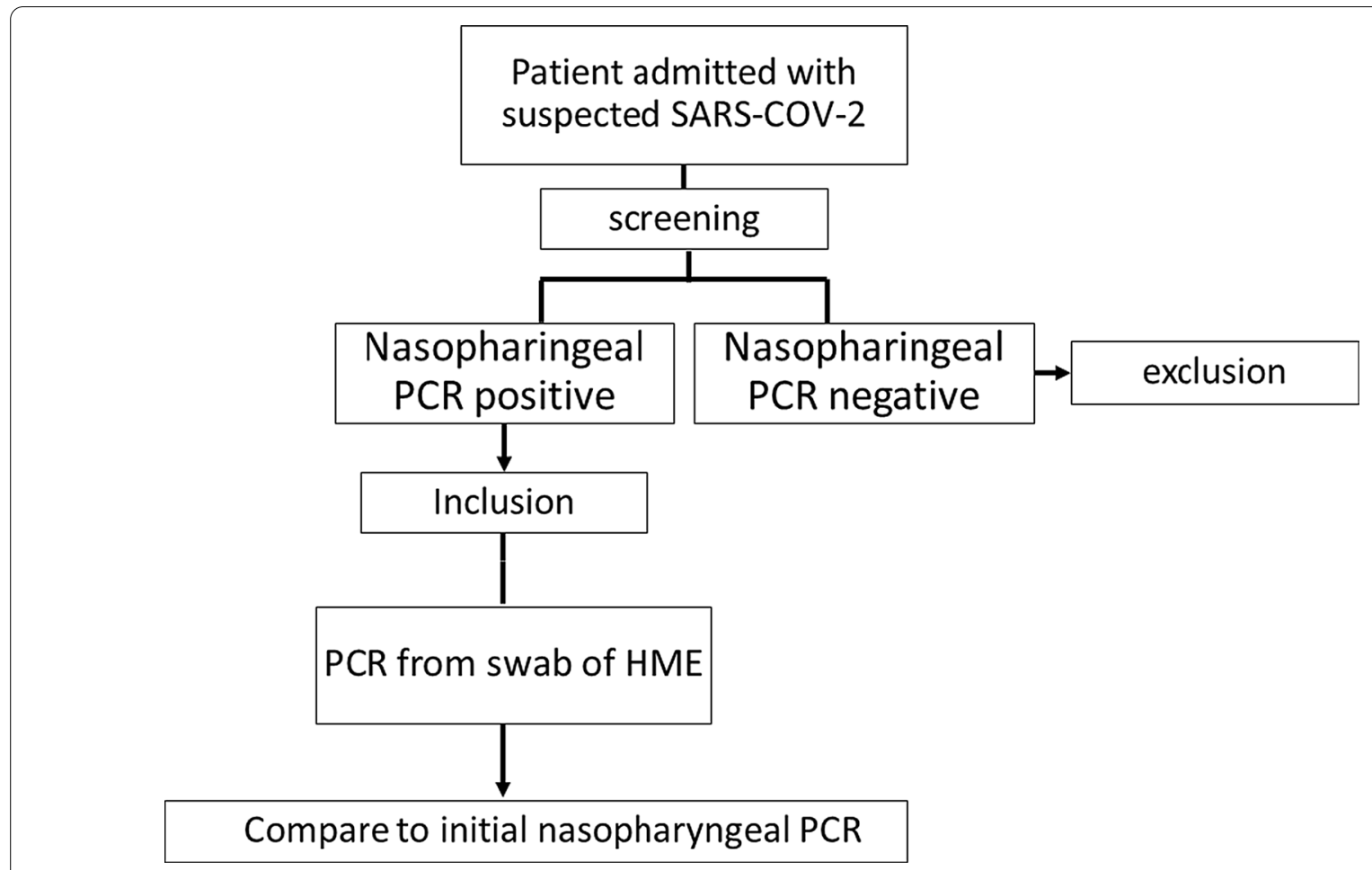

Fig. 1 Flowchart of study design 
render the technique less applicable and appealing for widespread use [5].

\section{Acknowledgements}

We thank Elizabeth Martinson, PhD, from the KHFI Editorial Office for her editorial assistance.

\section{Authors' contributions}

All authors were involved in the conception of the work, the interpretation of data as well as the drafting and revising the manuscript. All authors read and approved the final manuscript.

\section{Funding}

The study was funded by the local research institute (Kerckhoff Herzforschungsinstitut (KHFI)).

\section{Availability of data and materials}

Data can be made available upon request.

\section{Declarations}

Ethics approval and consent to participate

The study was approved by the local ethics committee. All patients participated with consent.

\section{Consent for publication}

Does not apply since no identifying information is presented.

\section{Competing interests}

There are no financial or nonfinancial disclosures that could be construed as a conflict of interest in regard to this manuscript.

\section{Author details}

1 Department of Cardiology, Kerckhoff Heart Center, Benekestr. 2-8, 61231 Bad Nauheim, Germany. ${ }^{2}$ DZHK (German Center for Cardiovascular Research),
Partner Site RheinMain, Frankfurt am Main, Germany. ${ }^{3}$ Department of Haemostaseology and Transfusion Medicine, Kerckhoff-Klinik, Bad Nauheim, Germany.

Received: 3 March 2021 Accepted: 23 March 2021

Published online: 30 March 2021

\section{References}

1. Wahidi MM, Lamb C, Murgu S, et al. American Association for Bronchology and Interventional Pulmonology (AABIP) statement on the use of bronchoscopy and respiratory specimen collection in patients with suspected or confirmed COVID-19 infection. J Bronchol Interv Pulmonol. 2020;27(4):e52-4.

2. Wang $W, X u Y$, Gao $R$, et al. Detection of SARS-CoV-2 in different types of clinical specimens. JAMA. 2020;323(18):1843-4.

3. McNeil JB, Shaver CM, Kerchberger VE, et al. Novel method for noninvasive sampling of the distal airspace in acute respiratory distress syndrome. Am J Respir Crit Care Med. 2018;197(8):1027-35.

4. May AK, Brady JS, Romano-Keeler J, et al. A pilot study of the noninvasive assessment of the lung microbiota as a potential tool for the early diagnosis of ventilator-associated pneumonia. Chest. 2015;147(6):1494-502.

5. Isaacs RJ, Debelak K, Norris PR, et al. Non-invasive detection of pulmonary pathogens in ventilator-circuit filters by PCR. Am J Transl Res. 2012;4(1):72-82.

\section{Publisher's Note}

Springer Nature remains neutral with regard to jurisdictional claims in published maps and institutional affiliations.
Ready to submit your research? Choose BMC and benefit from:

- fast, convenient online submission

- thorough peer review by experienced researchers in your field

- rapid publication on acceptance

- support for research data, including large and complex data types

- gold Open Access which fosters wider collaboration and increased citations

- maximum visibility for your research: over 100M website views per year

At $\mathrm{BMC}$, research is always in progress.

Learn more biomedcentral.com/submissions 